\title{
PENGUJIAN SISTEM INFORMASI INVENTORY PADA PERUSAHAAN DISTRIBUTOR FARMASI MENGGUNAKAN METODE BLACK BOX TESTING
}

\author{
Lila Setiyani \\ Sekolah Tinggi Informatika dan Komputer Rosma, Sistem Informasi \\ lila.setiyani@dosen.rosma.ac.id \\ Jl. Kertabumi No.62 Karawang 41311
}

\begin{abstract}
ABSTRAK
Pengelolaan dan pengontrolan produk sangat dibutuhkan oleh perusahaan yang bergerak di bidang distribusi farmasi, karena perusahaan distribusi farmasi membutuhkan perencanaan dan pengendalian persediaan dalam hal ini produk farmasi terkait dengan tanggal expired dan batch. Pada tahap analisis kebutuhan sistem terdapat beberapa prosedur yang terkait dengan inventory perusahaan distributor produk farmasi diantaranya adalah pengelolaan qoutation, sales order purchase order, penerimaan barang, retur barang, surat jalan, invoice, pembayaran, barang rusak dan pemusnahan barang. Sistem inventory untuk perusahaan distributor produk farmasi telah berhasil dibangun menggunakan metode Agile Unified Process dengan empat tahapan yaitu inception, elaboration, construction, dan transition. Pada tahapan transition dilakukan pengujian sistem inventory dengan menggunakan metode black box testing. Pengujian menggunakan black box testing ini bertujuan untuk mengetahui error yang terjadi ketika sistem digunakan oleh end user dengan pengujian data normal dan data tidak normal.
\end{abstract}

Kata kunci: inventory, agile unified process, black box testing

\section{PENDAHULUAN}

Pengelolaan inventory pada perusahaan distributor farmasi merupakan salah satu aset perusahaan. Pengelolaan ini mengontrol produk - produk farmasi yang didistribusikan ke perusahaan swasta yang bergerak di bidang jasa pelayanan kesehatan. Dalam pengelolaan inventory dilakukan perencanaan dan pengendalian dari persediaan barang. Produk farmasi memerlukan perhatian khusus, karena produk farmasi terkait dengan kadaluarsa produk yang penting untuk diidentifikasi ketika akan di keluarkan dari warehouse.

Pada proses pengembangan perangkat lunak sistem inventory untuk perusahaan distributor farmasi ini digunakan methodology agil unified process $(A U P)$ yang merupakan salah satu metode pengembangan perangkat lunak cepat. Dalam tahapan penggembangan menggunakan methodology agil unified process (AUP) ini terdapat empat tahapan yaitu inception, elaboration, construction, dan transition. Pada tahapan transition terdiri dari empat kegiatan yaitu system testing, user testing, system rework dan system deployment (Ambler, 2014). Pada kegiatan system testing dilakukan dengan melakukan pengujian menggunakan dokumen acceptence test yang beisikan pengujian black box testing yang bertujuan untuk mendapatkan umpan balik dari pengguna akhir.

Dalam atikel ini dibahas tentang proses pengujian black box testing untuk menguji sistem informasi inventory perusahaan distributor farmasi. Dengan pengujian black box testing ini diharapkan menghasilkan suatu sistem informasi yang memiliki kualitas dan sesuai dengan kebutuhan pengguna yaitu perusahaan distributor farmasi.

\section{LANDASAN TEORI}

2.1 Pengertian Inventory

Inventory mencakup aset yang di beli, di proses untuk menghasilkan barang atau layanan. Inventory disebut juga stock, trading stock atau inventory stock. Inventory tidak termasuk capital assets atau human resource dan juga tidak termasuk uang, kecuali uang dijadikan sebagai bagian jual beli seperti bank. (business.gov.au, 2018).

Pengaplikasian sistem informasi inventory sangat berpengaruh pada profit perusahaan. Ini dibuktikan dengan hasil penelitian Abdulraheem, dkk pada bisnis - bisnis kecil dalam periode 10 tahun di kota kwara, Nigeria . (Koan, 2014). 
Pada proses inventory terdapat istilah manajemen persediaan yang merupakan bagian yang bertanggung jawab dalam pengendalian persediaan. Manajemen persediaan bertanggung jawab membuat keputusan terhadap suatu kebijakan, kegiatan atau prosedur untuk memastikan perhitungan yang tepat terhadap segala hal yang ditangani dalam persediaan. (Abdul Bari, 2016).

\section{Produk Farmasi}

Sediaan farmasi adalah obat, obat tradisional dan kosmetika. Obat adalah bahan paduan bahan, termasuk produk biologi yang digunakan untuk mempengaruhi atau menyelidiki sistem fisiologi atau keadaan patologi dalam rangka penetapan diagnosisi, pencegahan, penyembuhan, pemulihan, peningkatan kesehatan dan kontraspsi, untuk manusia. Obat tradisional adalah bahan atau ramuan bahan yang berupa bahan tumbuhan, bahan hewan, bahan mineral, sediaan sarian, atau campuran dari bahan tersebut secara turun menurun telah digunakan untuk pengobatan dan diterapkan sesuai dengan norma yang berlaku di masyarakat (Sudibyo Supardi, 2012).

\section{Agile unified process}

Agile unified process adalah pendekatan pemodelan hibrida yang dibuat oleh Scott Ambler ketika ia menggabungkan Rational Unified Process ke metode Agile methods. Ambler menciptakan kerangka proses yang solid yang dapat diterapkan untuk semua jenis perangkat lunak baik proyek besar maupun kecil. Agile methods memberikan nilai, prinsip dan praktik ke Agile unified process. Nilai - nilai tersebut adalah memberikan perangkat lunak yang bekerja, berkolaborasi dengan pelanggan dan menanggapi perubahan termasuk memuaskan pelanggan (Edeki, 2013). berikut adalah tahapan dalam agile unified process :

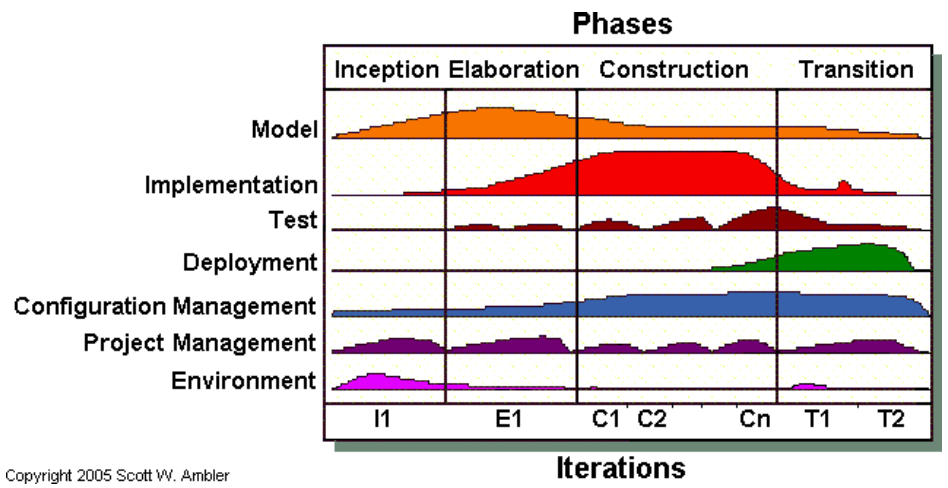

Gambar 2.1 Tahapan dalam pengembangan perangkat lunak menggunakan model agile unified process

Sumber gambar : (Edeki, 2013)

\section{Pengujian Perangkat Lunak}

Pengujian perangkat lunak bertujuan untuk memastikan, bahwa perangkat lunak yang telah dikembangkan sudah berjalan sesuai dengan fungsionalitas yang diharapkan pengguna akhir. Pengembang perangkat lunak melakukan sesi khusus untuk menguji perangkat lunak agar error dapat di deteksi sejak awal. Pengujian perangkat lunak ini menjamin kualitas perangkat lunak yang merupakan bagian dari daur hidup pengembangan perangkat lunak. (M. Sidi Mustaqbal, 2015).

Menurut Khan, jenis pengujian perangkat lunak terbagi menjadi dua yaitu white box testing dan blackbox testing. (M. Sidi Mustaqbal, 2015)

\subsection{Black box testing}

Black box testing merupakan pengujian kualitas perangkat lunak yang berfokus pada fungsionalitas perangkat lunak. Pengujian black box testing bertujuan untuk menemukan fungsi yang tidak benar, kesalahan antarmuka, kesalahan pada struktur data , kesalahan perfomansi , kesalahan inisialisasi dan terminasi. (M. Sidi Mustaqbal, 2015).

Dalam pengujian black box testing digunakan alat untuk pengumpulan data yang disebut dengan user acceptance test, dokumen ini terdiri deskripsi indikator dari prosedur - prosedur pengujian fungsionalitas dari perangkat lunak.

\section{METODE}

Metode yang digunakan dalam penelitian ini adalah metode penelitian kualitatif yang merupakan penelitian yang berusaha untuk mendiskrisikan hasil pengujian dengan mengintepretasikan data. 


\section{a. Pengumpulan Data}

Metode yang digunakan untuk mengumpulkan data adalah dengan menggunakan instrumen alat yaitu berupa dokumen user acceptance test yang merupakan bagian dari black box testing. Dalam dokumen user acceptance ini terdapat point - point dari fungsionalitas perangkat lunak yang akan di uji. Berikut adalah contoh dari dokumen user acceptance test.

\begin{tabular}{|c|c|c|c|c|c|c|c|c|}
\hline \multirow{3}{*}{\multicolumn{7}{|c|}{$\begin{array}{c}\text { User Acceptance Test } \\
\text { Document } \\
<<\text { Nama Aplikasi }>>\end{array}$}} & \multicolumn{2}{|c|}{ No Dok : } \\
\hline & & & & & & & \multirow{2}{*}{\multicolumn{2}{|c|}{$\begin{array}{l}\text { Penguji : } \\
\text { Butir Pengujian : }\end{array}$}} \\
\hline & & & & & & & & \\
\hline \multirow[t]{2}{*}{$\begin{array}{c}\text { ID } \\
\text { Pengujian }\end{array}$} & \multirow[t]{2}{*}{$\begin{array}{l}\text { Deskripsi } \\
\text { Pengujian }\end{array}$} & \multirow[t]{2}{*}{$\begin{array}{l}\text { Prosedur } \\
\text { Pengujian }\end{array}$} & \multirow[t]{2}{*}{$\begin{array}{c}\text { Data } \\
\text { Masukan }\end{array}$} & \multirow{2}{*}{$\begin{array}{l}\text { Keluaran } \\
\text { yang } \\
\text { diharapkan }\end{array}$} & \multirow{2}{*}{$\begin{array}{l}\text { Hasil } \\
\text { yang di } \\
\text { dapat }\end{array}$} & \multicolumn{3}{|c|}{$\begin{array}{c}\text { Hasil } \\
\text { Uji }\end{array}$} \\
\hline & & & & & & Diterima & $\begin{array}{r}\text { Diterima } \\
\text { dengan } \\
\text { syarat }\end{array}$ & Ditolak \\
\hline & & & & & & & & \\
\hline & & & & & & & & \\
\hline
\end{tabular}

Keterangan :

Nama Aplikasi

No Dok

Penguji

Butir Pengujian

ID Pengujian

Deskripsi Pengujian

Prosedur Pengujian

Data Masukan

Proses pengujian

Keluaran yang diharapkan

Hasil uji diterima

Hasil uji diterima dengan syarat Hasil uji ditolak
: Nama dari aplikasi yang diuji

: Nomor dari dokumen pengujian

: Aktor yang menguji, pengujian dapat dilakukan oleh pengembang perangkat lunak atau dari penguji eksternal.

: Menu yang di uji .

: Kode dari pengujian detail

: Deskripsi dari transaksi yang diuji

: Langkah - langkah untuk pengujian

: Data yang di entry ke dalam textbox atau field yang ada di form transaksi untuk

: Informasi yang diharapkan oleh penguji dari proses data.

: Pengujian telah diterima atau produk telah sesuai spesification

: Pengujian diterima namun dengan syarat tertentu.

: Pengujian yang dilakukan tidak dapat diterima hasilnya.

\section{b. Teknik Analisis}

Data hasil pengumpulan data kemudian dianalisis, analisis diambil dari hasil uji. Jika hasil uji ditolak maka pengembang perangkat lunak harus melakukan perbaikan secara mayor, sedangkan hasil uji di terima dengan syarat maka pengembang perangkat lunak akan melakukan perbaikan secara minor. Pengujian ini terus dilakukan sampai hasil uji dinyatakan ditermia secara keseluruhan.

\section{HASIL DAN PEMBAHASANA \\ 4.1 Tahap Pengujian}

Pengujian dilakukan dengan tahapan yang disesuaikan dengan aliran dokumen inventory yang berjalan pada perusahaan distributor farmasi tersebut. Tahapan pengujian di mulai dari pengujian menu quotation, menu sales order, menu surat jalan, menu invoice, menu penerimaan barang dan menu barang rusak atau penghapusan barang. 
Techno Xplore

ISSN: 2503-054X

Jurnal Ilmu Komputer dan Teknologi Informasi

Vol. 4 No: 1, April 2019

\subsection{Modul Pengujian}

\section{Pengujian Menu Quotation}

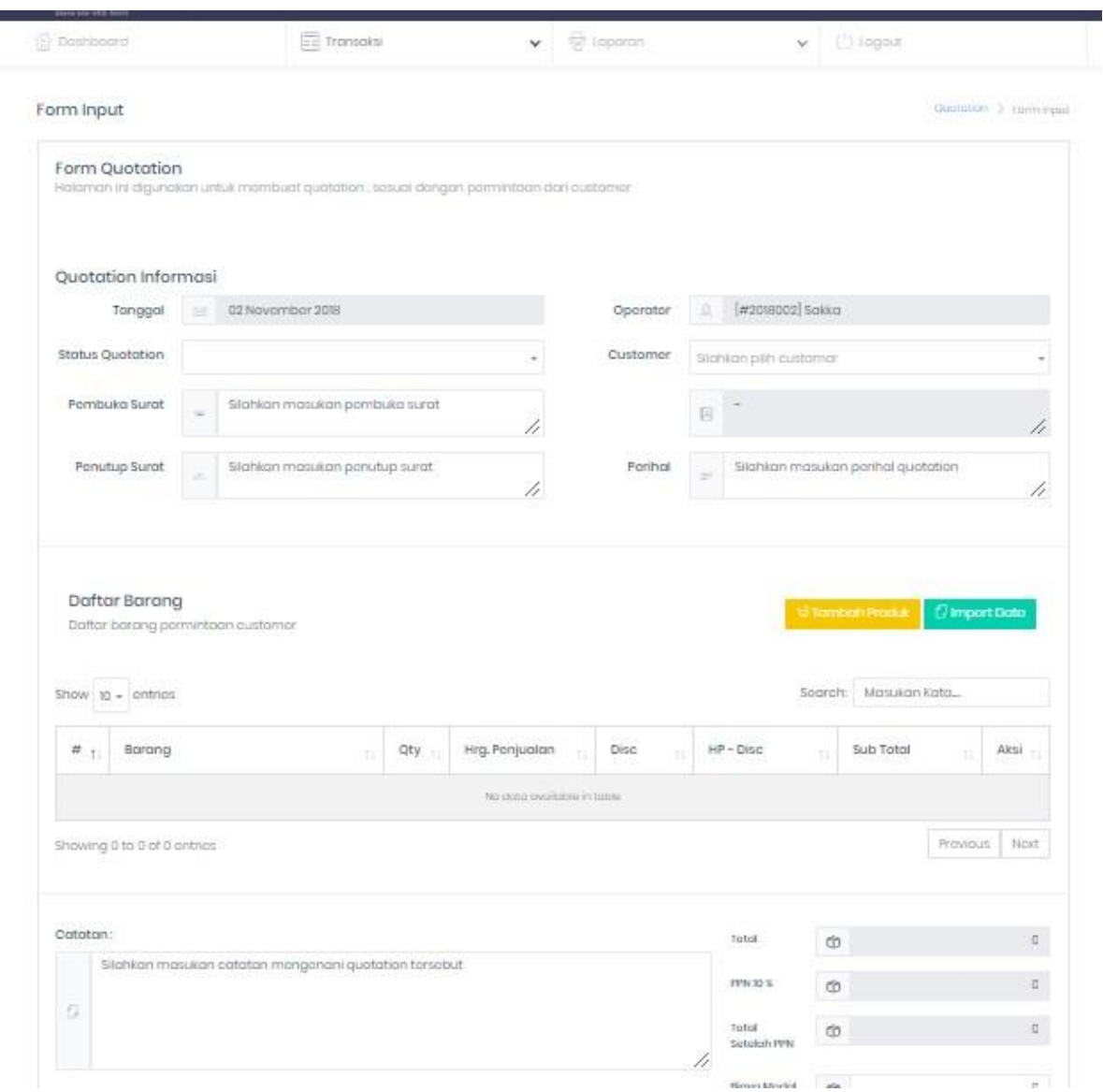

Gambar 4.1 Form quotation

Tabel 4.1 User Acceptance Menu Quotation

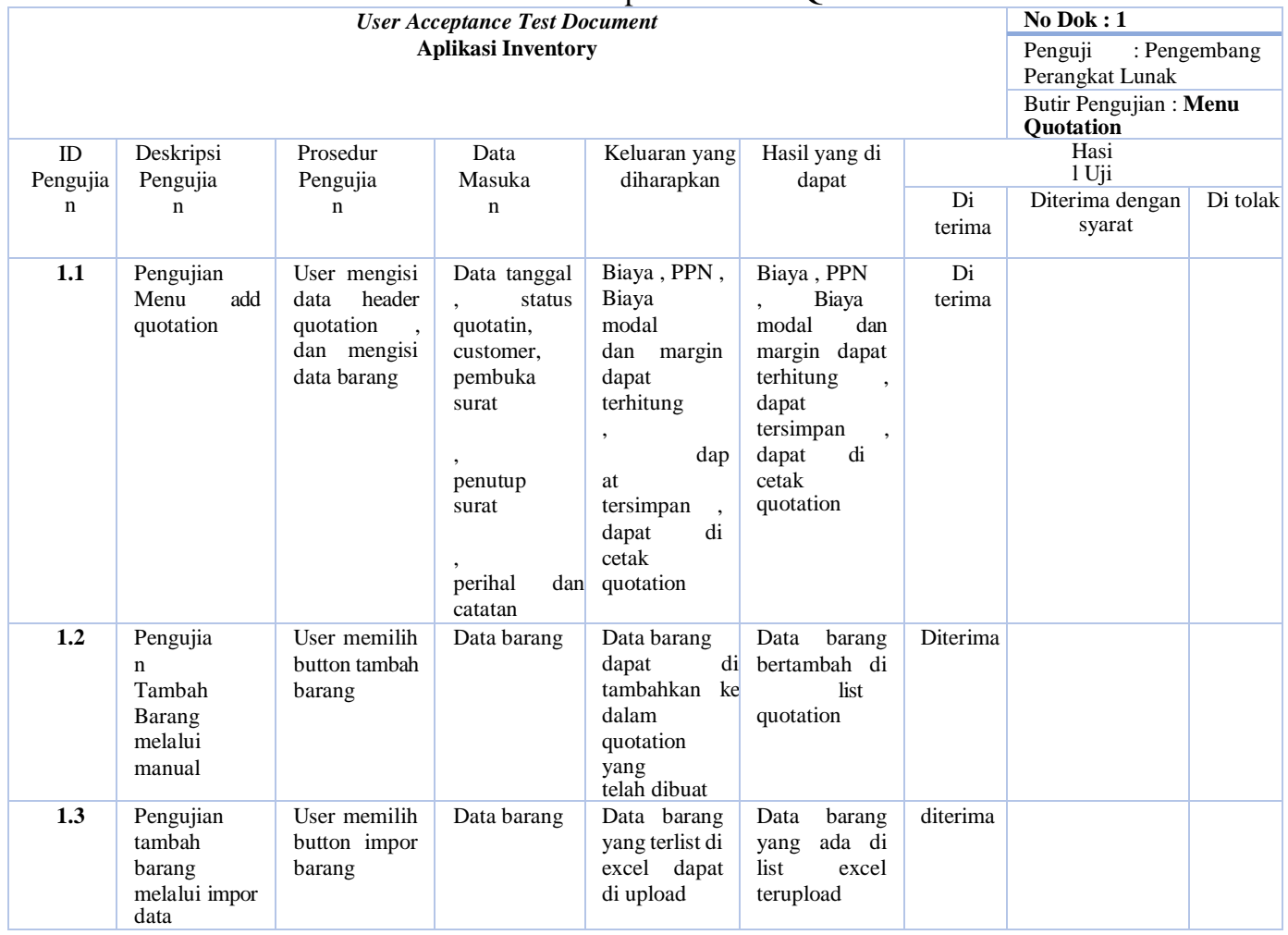




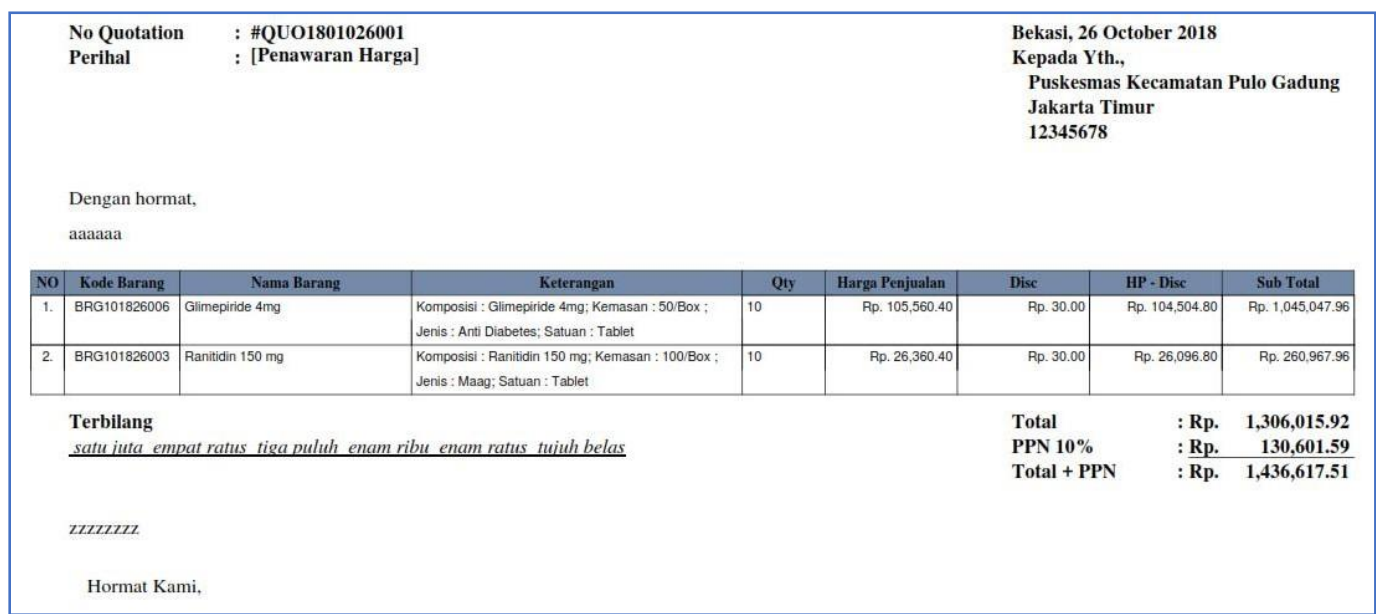

Gambar 4.2 Hasil cetak menu quotation

\section{Pengujian Menu Sales Order}

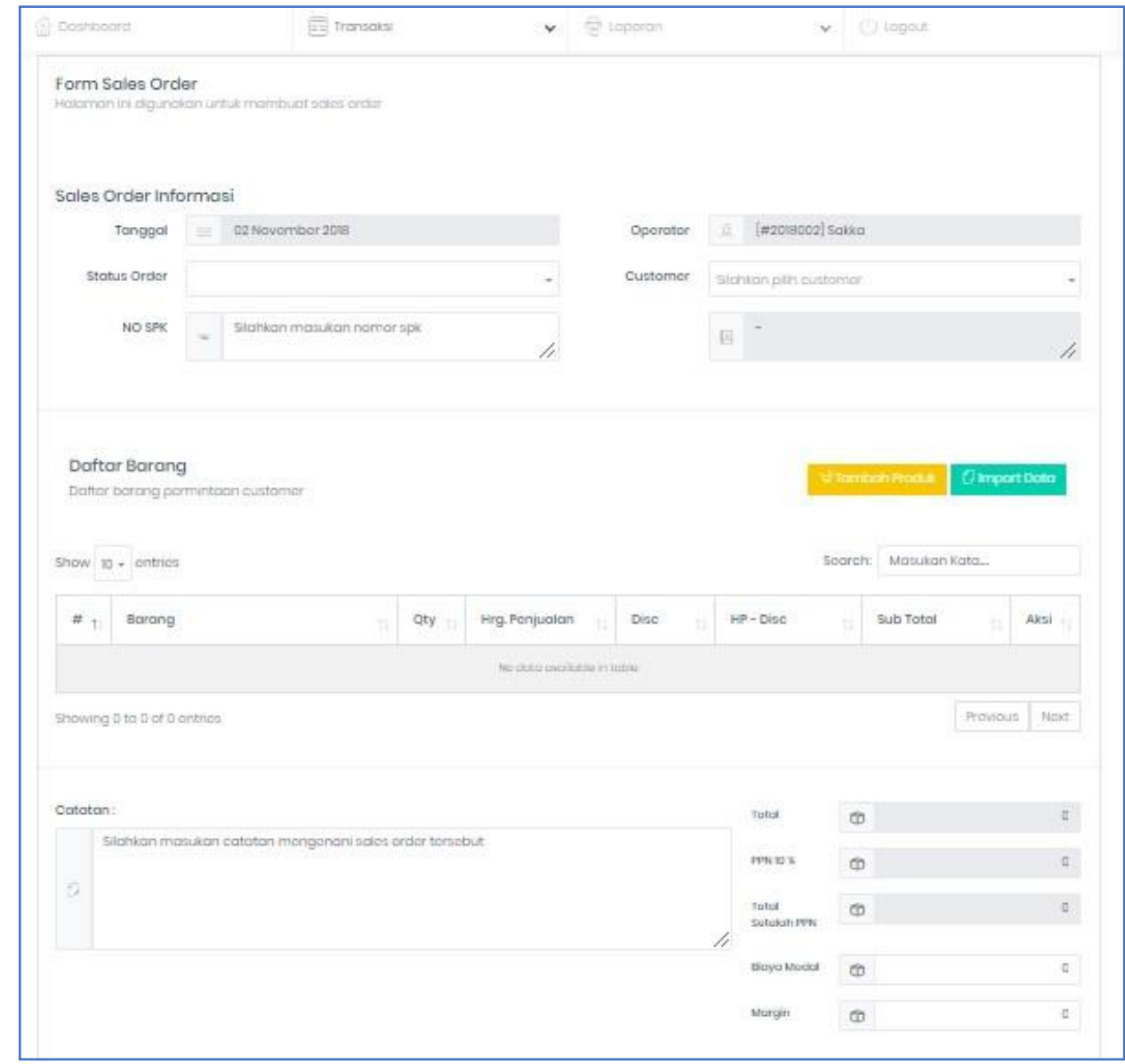

Gambar 4.3 Form input sales order 
Techno Xplore

ISSN: 2503-054X

Jurnal Ilmu Komputer dan Teknologi Informasi

Vol. 4 No: 1, April 2019

Tabel 4.2 Dokumen user acceptance test menu Sales Order

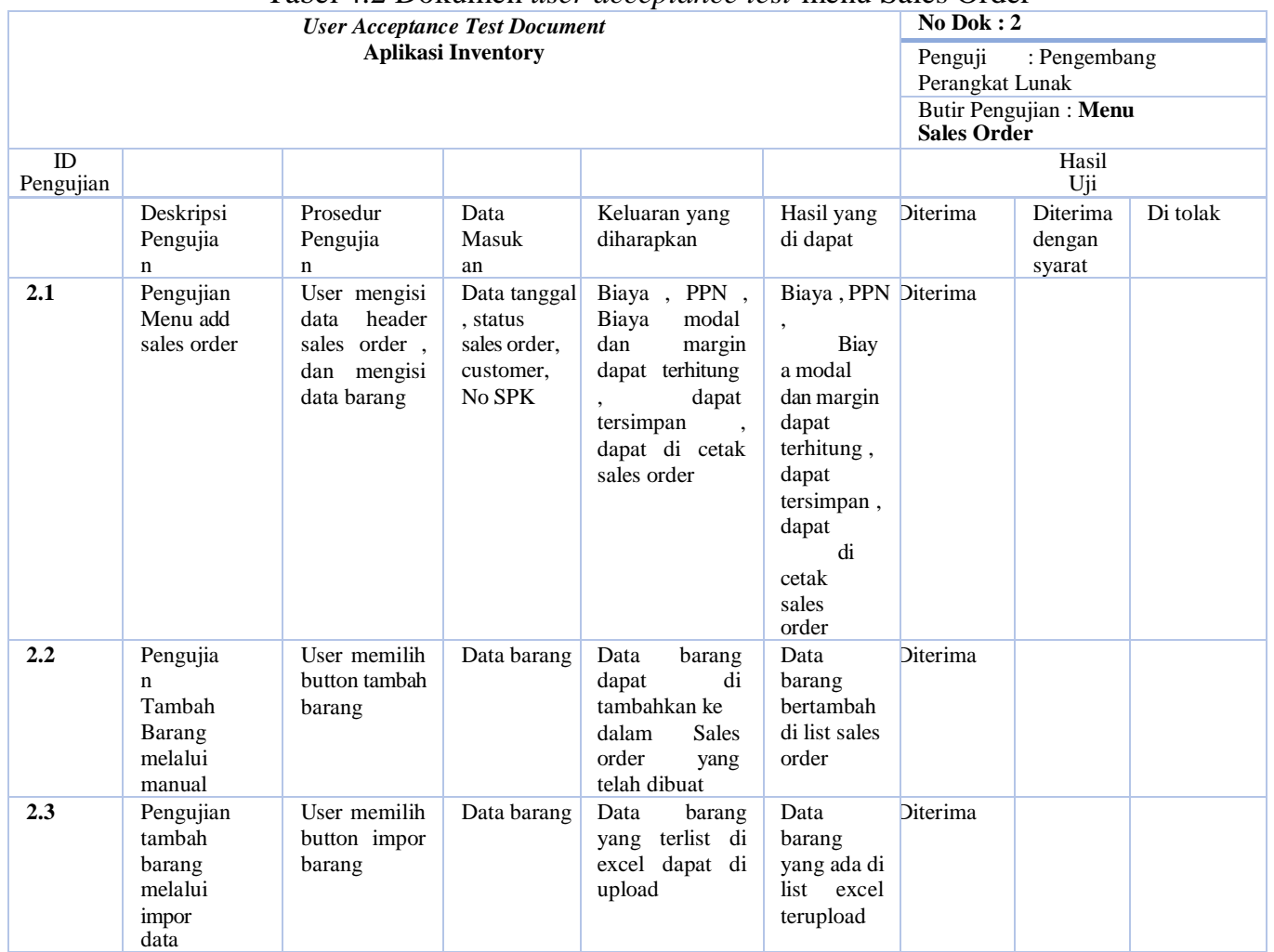

\section{Pengujian Menu Surat Jalan}

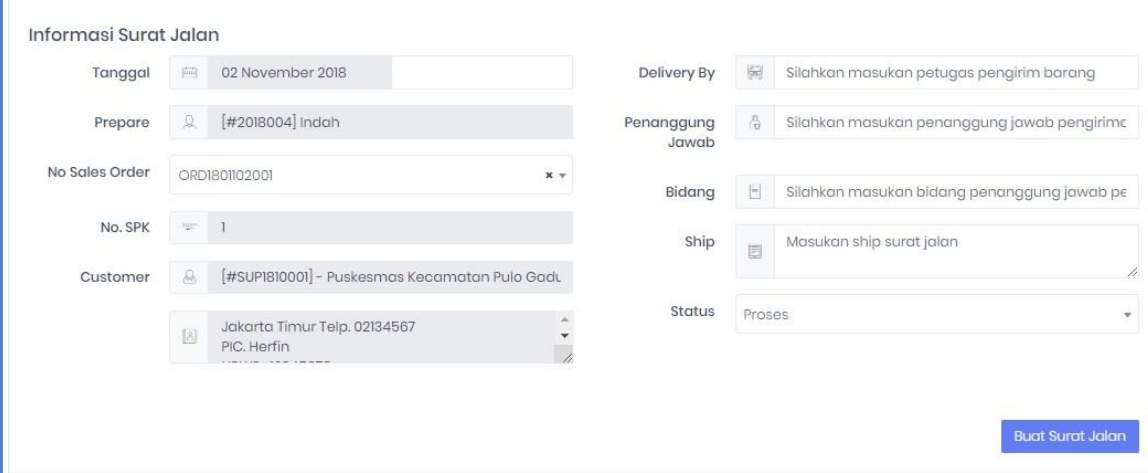

Gambar 4.4 Form untuk membuat entry header surat jalan 


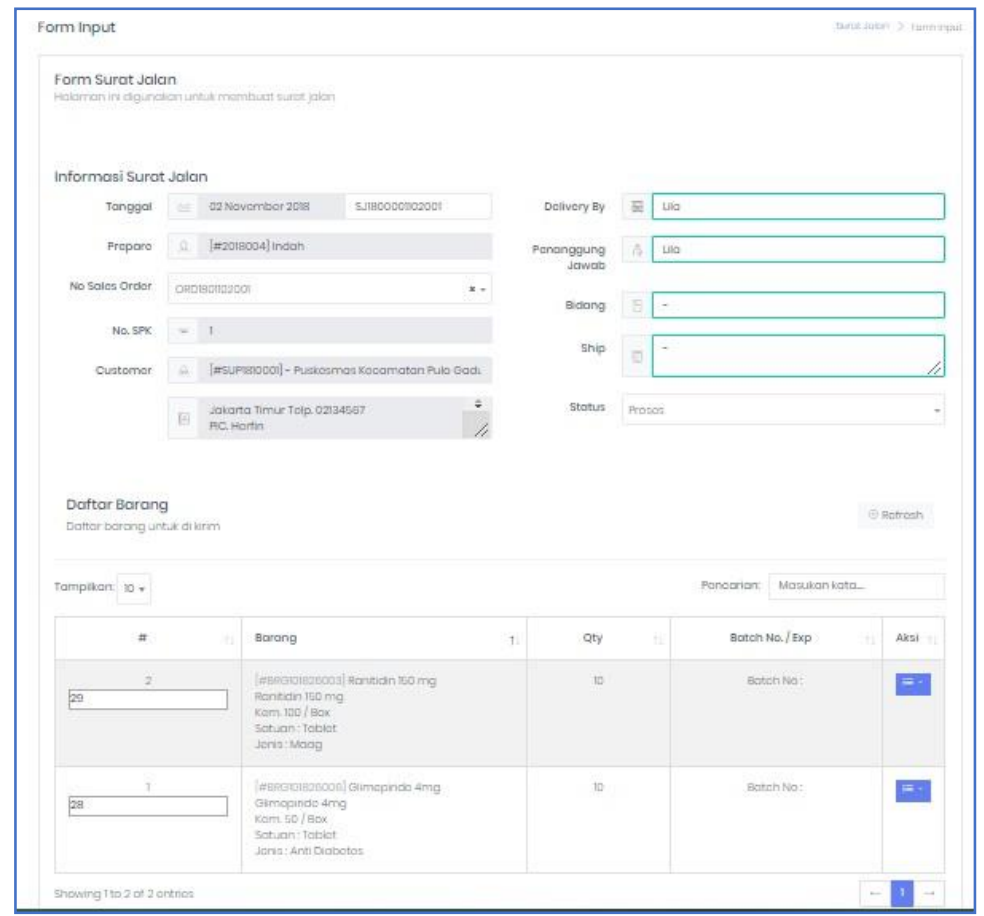

Gambar 4.5 form entry detail barang surat jalan Tabel 4.3 Dokumen User Acceptance Test menu

\begin{tabular}{|c|c|c|c|c|c|c|c|c|}
\hline \multicolumn{9}{|c|}{ surat jalan } \\
\hline \multirow{2}{*}{\multicolumn{7}{|c|}{ Aplikasi Inventory }} & \multicolumn{2}{|c|}{$\begin{array}{l}\text { Penguji : Pengembang } \\
\text { Perangkat Lunak }\end{array}$} \\
\hline & & & & & & & \multicolumn{2}{|c|}{$\begin{array}{l}\text { Butir Pengujian : Menu } \\
\text { Surat Jalan }\end{array}$} \\
\hline \multirow[t]{2}{*}{$\begin{array}{l}\text { ID } \\
\text { Pengujian }\end{array}$} & \multirow[t]{2}{*}{$\begin{array}{l}\text { Deskripsi } \\
\text { Pengujian }\end{array}$} & \multirow[t]{2}{*}{$\begin{array}{l}\text { Prosedur } \\
\text { Pengujian }\end{array}$} & \multirow[t]{2}{*}{$\begin{array}{l}\text { Data } \\
\text { Masukan }\end{array}$} & \multirow{2}{*}{$\begin{array}{l}\text { Keluaran } \\
\text { yang } \\
\text { diharapkan }\end{array}$} & \multirow[t]{2}{*}{$\begin{array}{l}\text { Hasil yang } \\
\text { di dapat }\end{array}$} & \multicolumn{3}{|c|}{$\begin{array}{c}\text { Hasil } \\
\text { Uji }\end{array}$} \\
\hline & & & & & & Di terima & $\begin{array}{l}\text { Diterima } \\
\text { dengan } \\
\text { syarat }\end{array}$ & $\begin{array}{l}\mathrm{Di} \\
\text { tolak }\end{array}$ \\
\hline 2.1 & $\begin{array}{l}\text { Pengujian } \\
\text { Menu add } \\
\text { Surat Jalan }\end{array}$ & $\begin{array}{l}\text { User mengisi } \\
\text { data header } \\
\text { surat jalan }\end{array}$ & $\begin{array}{l}\text { Data tanggal } \\
\text {, prepare, no } \\
\text { SO, noSPK, } \\
\text { customer, } \\
\text { delivery, } \\
\text { penanggung } \\
\text { jawab, } \\
\text { bidang, ship } \\
\text {, status }\end{array}$ & $\begin{array}{l}\text { Data dapat } \\
\text { tersimpan } \\
\text { dan } \\
\text { menuju } \\
\text { form untuk } \\
\text { mengisi } \\
\text { jumah } \\
\text { barang }\end{array}$ & $\begin{array}{l}\text { Data dapat } \\
\text { tersimpan } \\
\text { dan menuju } \\
\text { form untuk } \\
\text { mengisi } \\
\text { jumah } \\
\text { barang }\end{array}$ & Di terima & & \\
\hline 2.2 & $\begin{array}{l}\text { Pengujian } \\
\text { tambah atau } \\
\text { edit jumlah } \\
\text { barang }\end{array}$ & $\begin{array}{l}\text { User mengisi } \\
\text { jumlah barang }\end{array}$ & $\begin{array}{l}\text { Jumlah } \\
\text { barang }\end{array}$ & $\begin{array}{l}\text { Data } \\
\text { tersimpan } \\
\text { dan } \\
\text { kemudian } \\
\text { dapat } \\
\text { dicetak }\end{array}$ & $\begin{array}{l}\text { Data } \\
\text { tersimpan } \\
\text { dan } \\
\text { kemudian } \\
\text { dapat } \\
\text { dicetak }\end{array}$ & Diterima & & \\
\hline
\end{tabular}

\section{KESIMPULAN}

Pengujian perangkat lunak menggunakan metode black box testing terbukti memberikan kemudahan kepada penguji perangkat lunak dalam hal pengujian fungsinalitas perangkat lunak . Dapat terlihat pada setiap pengujian terdapat keputusan diterima, di terima dengan syarat dan ditolak, dengan keputusan ini pengembang perangkat lunak dapat dengan mudah untuk melakukan perbaikan karena point - point yang harus diperbaiki sudah jelas pada ID pengujian. Dengan metode black box testing ini pengembang perangkat lunak sistem informasi inventory perusahaan bidan farmasi dapat menguji keseluruhan fitur atau menu yang terdapat pada sistem tersebut.

\subsection{Saran}

Pada artikel ini peneliti hanya menjelaskan proses pengujian fungsionalitas perangkat lunak, untuk selanjutnya peneliti dapat menjeaskan proses pengujian untuk menguji kebermanfaatan perangkat lunak yaitu uji usability. Dengan menggunakan uji usability ini perangkat lunak dapat diukur tingkat kebermanfaatannya. 


\section{DAFTAR PUSTAKA}

Abdul Bari, K. (2016). Sistem Informasi Manajemen Inventory Secara Online menggunakan Framework EasyUI. Jurnal Inovtek Polbeng - Seri Informatika, Vol. 1 No.1, Juni 2016, 7886.

Ambler, S. W. (2014). The Agile Unified Process (AUP). Diambil kembali dari www.ambysoft.com: http://www.ambysoft.com/unifiedprocess/agileUP.html

business.gov.au. (2018, July 24). Inventory management. Diambil kembali dari www.business.gov.au: https://www.business.gov.au/products-and-services/inventorymanagement

Edeki, C. (2013). Agile Unified Process. International Jurnal of Computer Science and Mobile Aplication Vol.1 Issue 3 Sepetember 2013, 13-17.

Government, B. A. (2018, July 24). Inventory Management. Diambil kembali dari Business: https://www.business.gov.au/products-and-services/inventory-management

Koan, D. F. (2014). Penerapan Inventory Management dalam Meningkatkan Profitabilitas di Toko X Kupang.

Jurnal Ilmiah Mahasiswa Universitas Surabaya Vol. 3 No. 1, 1-16.

M. Sidi Mustaqbal, R. F. (2015). Pengujian Aplikasi Menggunakan Black Box testing Boundary Values Analysis. Jurnal Ilmiah Teknologi Informasi Terapan Vol. 1 , No 3, 10 Agustus 2015, 31-36.

Pontius, N. (2018, June 28). What is an Inventory Management System? Definition of Inventory Management Systems, Benefits, Best Practices \& More. Diambil kembali dari Camecode: https://www.camcode.com/asset-tags/what-is-an-inventory-management-system/

Sudibyo Supardi, R. S. (2012). Kajian peraturan Perudang - undangan tentang Pemberian Informasi Obat dan Obat Tradisional di Indonesia. Jurnal Kefarmasian Indonesia, Vol.2.1.2017, 2027. 